\title{
The Obstetric Outcomes in Women with Preeclampsia and Superimposed Preeclampsia
}

\author{
Preeklampsi ve Süperimpoze Preeklampsi Olgularında \\ Obstetrik Sonuçlar
}

\section{Arife ȘiMŞEK, ${ }^{\text {a }}$ \\ Seyfettin ULUDAĞ, ${ }^{a}$ \\ Abdullah TÜTEN, ${ }^{a}$ \\ Sezin ULUDAĞ ${ }^{a}$}

aDepartment of Obstetric and Gynecology, İstanbul University

Cerrahpaşa Faculty of Medicine,

İstanbul

Geliş Tarihi/Received: 04.11.2016

Kabul Tarihi/Accepted: 07.02.2017

Yazışma Adresi/Correspondence: Arife ŞIMŞEK

İstanbul University

Cerrahpaşa Faculty of Medicine,

Department of Obstetric and Gynecology, İstanbul,

TURKEY/TÜRKIYE

draksimsek@yahoo.com.tr

This manuscript has been presented in the form of an abstract for the 15th World Congress in Fetal Medicine, 26-30 June 2016, Spain.

\begin{abstract}
Objective: This study was performed to compare the obstetric outcomes between preeclampsia and superimposed preeclampsia cases. Material and Methods: This retrospective study included 500 women with preeclampsia and 101 women with superimposed preeclampsia who delivered in a tertiary care center. Clinical findings, maternal and perinatal outcomes were compared between the two groups. Results: In cases of preeclampsia, antenatal, perinatal, neonatal mortality rates were $13.4 \%, 17.9 \%, 5.1 \%$ respectively. The rate of cases which mother's life at risk was $30.2 \%$. The antenatal, perinatal and neonatal mortality rates were $12.9 \%, 19.8 \%$, and $8.9 \%$, respectively, in cases of superimposed preeclampsia and the rate of cases where mother's life was at risk was $25.7 \%$. There was no significant difference between the two groups in terms of time of onset of the symptoms $(\mathrm{p}=0.669)$, mean birth week $(\mathrm{p}=0.410)$ and birth weight $(\mathrm{p}=0.340)$. Rates of intrauterine growth retardation $(\mathrm{p}=0.434)$, early and late neonatal loss $(\mathrm{p}=0.111, \mathrm{p}=0.848)$ and stillbirth $(\mathrm{p}=$ 0.887 ) did not differ between the groups. Although maternal deaths and maternal near miss cases were not significantly different between the two groups ( $\mathrm{p}=0.370$ ), the rate of complication with eclampsia in preeclampsia cases was higher than that of superimposed preeclampsia cases $(\mathrm{p}=0.001)$. Conclusion: Preeclampsia and superimposed preeclampsia have similar obstetric outcomes. Further research is needed to elucidate the mechanisms underlying eclampsia in preeclampsia cases.
\end{abstract}

Keywords: Pre-eclampsia; perinatal mortality; maternal mortality; pregnancy outcome

ÖZET Amaç: Bu çalışma preeklampsi ve süperimpoze preeklampsi olgularının obstetrik sonuçlarını karşılaştırmak amacıyla gerçekleştirilmiştir. Gereç ve Yöntemler: Bu çalışmaya üçüncü basamak bir sağlık biriminde doğumları gerçekleştirilen 500 preeklampsili ve 101 süperimpoze preeklampsili gebe dahil edildi. Hasta dosyaları geriye dönük olarak incelendi. İki grup arasında klinik bulgular, maternal ve perinatal sonuçlar karşılaştırıldı. Bulgular: Preeklampsi olgularında antenatal, perinatal ve neonatal mortalite oranları sırasıyla \%13.4, \%17.9, \%5.1, anne hayatının risk altında olduğu olguların oranı \%30.2 idi. Süperimpoze preeklampsi olgularında antenatal, perinatal ve neonatal mortalite oranları sırasıyla \%12.9, \%19.8, \%8.9, anne hayatının risk altında olduğu olguların oranı \%25.7 idi. Semptomların ortaya çıkış zamanı (p: 0.669), ortalama doğum haftası (p: 0.410) ve doğum kilosu (p: 0.340 ) açısından iki grup arasında anlamlı fark saptanmadı. İntrauterin büyüme geriliği (p: 0.434), erken ve geç neonatal kayıp (p: 0.111, p: 0.848) ve ölü doğum (p: 0.887) oranları gruplar arasında farklı değildi. Annenin öldüğü ya da ölümden döndüğ̈̈ olgular her iki grup arasında anlamlı fark göstermemekle birlikte (p: 0.370), preeklampsi olgularında eklampsi ile komplike olma oranı süperimpoze preeklampsi olgularına göre daha yüksek idi (p: 0.001). Sonuç: Preeklampsi ve süperimpoze preeklampsi olguları benzer obstetrik sonuçlara sahiptir. Eklampsinin preeklampsili olgularda daha fazla görülmesinin altında yatan mekanizmaları aydınlatmak için ileri çalışmalara ihtiyaç vardır.

Anahtar Kelimeler: Pre-eklampsi; perinatal mortalite; anne ölümü; gebelik sonucu

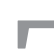
here is an increasing tendency towards delayed childbearing. The risk of hypertensive disorders in pregnancy increases gradually with age. ${ }^{1}$ The hypothesis that superimposed preeclampsia results in worse 
pregnancy outcomes than preeclampsia continues to be the subject of debate. ${ }^{2}$ Superimposed preeclampsia is a severe form of the disease. Besides, aggressive management of superimposed preeclampsia has been thought to cause increased risks of intervention-related events. ${ }^{2}$

This study was performed to identify and compare the maternal and fetal outcomes of the patients having preeclampsia and superimposed preeclampsia diagnosis.

\section{MATERIAL AND METHODS}

This retrospective study included 601 women with preeclampsia who delivered in a tertiary care center over a ten year-period. Of 601 women, 500 had preeclampsia and 101 had superimposed preeclampsia. Clinical findings, maternal and perinatal outcomes were compared between the two groups.

The study was conducted in accordance with the ethical principles stated in the Declaration of Helsinki, and an approval was obtained from the Human Ethics Committee of the Institution. Preeclampsia and features of severity were defined according to criteria provided by American College of Obstetricians and Gynecologists (ACOG) in 2013; blood pressure elevation after 20 weeks of gestation with proteinuria or any of the severe features of preeclampsia. ${ }^{3}$ Chronic hypertension was defined as systolic pressure $\geq 140 \mathrm{mmHg}$ and/or diastolic pressure $\geq 90 \mathrm{mmHg}$ that antedates pregnancy or is present before the $20^{\text {th }}$ week of pregnancy (on at least two occasions). Patients with both primary and secondary hypertension were included. Superimposed preeclampsia was defined by the new onset of either proteinuria or end-organ dysfunction after 20 weeks of gestation in a woman with chronic hypertension. For women with chronic hypertension who have proteinuria prior to or in early pregnancy, superimposed preeclampsia was defined by worsening or resistant hypertension (especially acutely) in the last half of pregnancy or development of signs/symptoms of the severe spectrum of the disease. Diagnostic criteria for severe preeclampsia were: 1-Hypertension: systolic $>160 \mathrm{mmHg}$ or diastolic $>110 \mathrm{mmHg}$ on two occasions at least 4 hours apart while the patient is on bed rest (unless antihypertensive therapy is initiated before this time). 2- Thrombocytopenia (platelet count $<100,000 /$ microliter). 3 Impaired liver function (elevated blood levels of liver transaminases to twice the normal concentration), severe persistent right upper quadrant or epigastric pain unresponsive to medication and not accounted for alternative diagnosis, or both. 4New development of renal insufficiency (elevated serum creatinine greater than $1.1 \mathrm{mg} / \mathrm{dl}$, or doubling of serum creatinine in the absence of other renal diseases). 5- Pulmonary edema. 6- New-onset cerebral or visual disturbances. ${ }^{3}$

Gestational age was determined according to the last menstrual period and/or to the crownrump length at first trimester ultrasound. Intrauterine growth restriction (IUGR) was defined as a birth weight $<10^{\text {th }}$ percentile for gestational age. Perinatal mortality was defined as the number of stillbirths and deaths in the first week of life. Maternal deaths and maternal near- miss cases were defined in respect of World Health Organization/ International Classification of Diseases-10 (WHO/ICD-10) definitions. ${ }^{4}$ Only maternal deaths and maternal near-miss cases caused by hypertension were accepted as maternal deaths and maternal near miss cases. The demographic and clinical characteristics of the study groups were recorded at hospital admission and presented in Table 1.

All women with severe symptoms were hospitalized. Women without severe symptoms were also hospitalized if they had fetal indications such as non-reassuring fetal status according to cardiotocography and umbilical artery Doppler assessment with an absent or reversed end-diastolic flow, IUGR/oligohydramnios, fetal demise, etc. Magnesium sulfate for eclamptic seizure prophylaxis and acute antihypertensive therapy were administered to women with severe preeclampsia when it is deemed necessary within the indications. Antenatal steroid was administered for fetal lung maturity to all pregnancies less than 34 weeks of gestational age. Indications for delivery were severe preeclampsia, uncontrollable blood pressure, diagnosis of HELLP (Hemolysis, elevated liver enzymes, and low platelets) syndrome, eclamptic 


\begin{tabular}{|c|c|c|c|}
\hline & Preeclampsia $n=500(\%)$ & Superimposed preeclampsia $n=101(\%)$ & $\mathrm{p}$ value \\
\hline Maternal age (year) & $28.3 \pm 6$ & $32.1 \pm 6.5$ & 0.000 \\
\hline Nulliparity & $279(55.8)$ & $36(35.6)$ & 0.000 \\
\hline Prior term delivery & $196(39.2)$ & $58(57.4)$ & 0.001 \\
\hline History of preterm delivery & $28(5.6)$ & $13(12.9)$ & 0.008 \\
\hline History of immature delivery & $13(2.6)$ & $3(3)$ & 0.833 \\
\hline History of stillbirth & $26(5.2)$ & $9(8.9)$ & 0.146 \\
\hline History of abortion & & & 0.232 \\
\hline Before the $12^{\text {th }}$ week of gestation & $80(16)$ & $21(20.8)$ & 0.240 \\
\hline After the $12^{\text {th }}$ week of gestation & $13(2.6)$ & $3(3)$ & 0.833 \\
\hline History of elective abortion & $58(11.6)$ & $19(18.8)$ & 0.048 \\
\hline History of preeclampsia/eclampsia & $21(4.2)$ & $9(8.9)$ & 0.047 \\
\hline History of cesarean delivery & $37(7.4)$ & $16(15.8)$ & 0.006 \\
\hline Smoking & $33(6.6)$ & $5(5)$ & 0.534 \\
\hline \multicolumn{4}{|l|}{ Systemic disease } \\
\hline Diabetes Mellitus & $17(3.4)$ & $12(11.9)$ & 0.000 \\
\hline Antenatal care & $354(70.8)$ & $84(83.2)$ & 0.011 \\
\hline Gender of fetus & & & 0.044 \\
\hline Male & $257(51.4)$ & $63(62.4)$ & \\
\hline Female & $243(48.6)$ & $38(37.6)$ & \\
\hline Highest systolic pressure & $167 \pm 23.23$ & $172 \pm 27.7$ & 0.784 \\
\hline Highest diastolic pressure & $106.3 \pm 14.3$ & $106.6 \pm 16$ & 0.922 \\
\hline Mean arterial pressure & $126.6 \pm 16.1$ & $128.6 \pm 18.9$ & 0.876 \\
\hline Beginning of the symptoms & & & 0.669 \\
\hline Before the $34^{\text {th }}$ week of gestation & $226(45.2)$ & $48(47.5)$ & \\
\hline After the $34^{\text {th }}$ week of gestation & $274(54.8)$ & $53(52.5)$ & \\
\hline
\end{tabular}

For those variables not distributed normally, two groups were compared with Mann-Whitney U Test. Chi-square test for independence was used for the analysis of categorical variables.

seizures or non-reassuring fetal status according to cardiotocography and umbilical artery Doppler assessment with an absent or reversed end-diastolic flow, fetal demise. Spontaneous labor was also an indication for delivery.

Statistical Package of the Social Sciences (SPSS) 17.0 software (SPSS Inc., Chicago, USA) was used for the statistical analyses. Data were expressed as $\mathrm{n}(\%)$ and mean with standard deviation. Quantitative variables were tested for normal distribution (by Kolmogorov-Smirnov Test) and homogeneity (by One-Way Anova Test). For those variables not distributed normally, two groups were compared with Mann-Whitney U Test. Chisquare test for independence was used for the analysis of categorical variables. A p value $<0.05$ was considered as significant.

\section{RESULTS}

In preeclampsia cases, the mean maternal age was $28.3 \pm 6$ years, mean gestational week at delivery was $33.9 \pm 3.9$ weeks, mean birth weight was 1971 $\pm 893 \mathrm{~g}$. Rates of antenatal, perinatal, neonatal mortality were, $13.4 \%, 17.9 \%$ and $5.1 \%$ respectively. Maternal life threatening conditions (maternal mortality + maternal near miss) were existing in $30.2 \%$ of the cases. In superimposed preeclampsia cases, the mean maternal age was $32.1 \pm 6.5$ years, mean gestational week at delivery was $33.4 \pm 4.2$ weeks, mean birth weight was $1891 \pm 951 \mathrm{~g}$. Rates of antenatal, perinatal, neonatal mortality were, $12.9 \%, 19.8 \%$ and $8.9 \%$ respectively. Maternal life threatening conditions were existing in $25.7 \%$ of the patients (Table 1 and Table 2). 


\begin{tabular}{|lccc|}
\hline \multicolumn{4}{|c|}{ TABLE 2: The obstetric outcomes in women with preeclampsia and superimposed preeclampsia. } \\
\hline & Preeclampsia $n=500(\%)$ & Superimposed preeclampsia $n=101$ (\%) & p value \\
Gestational week at delivery & $33.9 \pm 3.9$ & $33.4 \pm 4.2$ & 0.410 \\
Birth before the $34^{\text {th }}$ week of gestation & $226(45.2)$ & $46(45.5)$ & 0.949 \\
Birth before the $37^{\text {th }}$ week of gestation & $357(71.4)$ & $71(70.3)$ & 0.823 \\
Birth weight (g) & $1971 \pm 893$ & $1891 \pm 951$ & 0.340 \\
Stillbirth & $67(13.4)$ & $13(12.9)$ & 0.887 \\
Early neonatal death & $21(4.3)$ & $8(7.9)$ & 0.111 \\
Perinatal mortality & $88(17.9)$ & $20(19.8)$ & 0.599 \\
Late neonatal death & $4(0.8)$ & $1(1)$ & 0.848 \\
Neonatal mortality & $25(5.1)$ & $9(8.9)$ & 0.121 \\
IUGR & $194(38.8)$ & $35(34.7)$ & 0.434 \\
Maternal mortality and maternal near-miss cases & $151(30.2)$ & $26(25.7)$ & 0.370 \\
Eclampsia & $71(14.2)$ & $2(2)$ & 0.001 \\
HELLP syndrome & $72(14.4)$ & $16(15.8)$ & 0.709 \\
Severe symptoms & $384(76.8)$ & $74(73.3)$ & 0.447 \\
Cesarean section rate & $353(70.6)$ & $63(62.4)$ & 0.102 \\
\hline
\end{tabular}

For those variables not distributed normally, two groups were compared with Mann-Whitney $U$ Test. Chi-square test for independence was used for the analysis of categorical variables. IUGR: Intrauterine growth retardation; HELLP: Hemolysis, elevated liver enzymes, and low platelets.

There were 5 maternal deaths. Deaths were occurred due to intraventricular hemorrhage (IVH) in 2 women with eclampsia, multiple organ failure (MOF) in a woman with HELLP syndrome, subarachnoid hemorrhage (SAH) and $\mathrm{MOF}$ in a woman with HELLP syndrome and eclampsia, hypertensive encephalopathy and acute renal failure (ARF) in a woman with HELLP syndrome and eclampsia.

Incidence of nulliparity was significantly higher in women with preeclampsia compared to ones with superimposed preeclampsia $(\mathrm{p}=0.000)$. The mean maternal age $(\mathrm{p}=0.000)$, previous term and preterm birth rates $(\mathrm{p}=0.001, \mathrm{p}=0.008)$, history of elective abortion $(\mathrm{p}=0.048)$, history of cesarean delivery $(\mathrm{p}=0.006)$, history of preeclampsia/eclampsia $(\mathrm{p}=0.047)$, accompanying systemic diseases such as diabetes mellitus $(\mathrm{p}=0.000)$, patients with antenatal care $(\mathrm{p}=0.011)$ were significantly higher in women with superimposed preeclampsia. Male predominance was also seen in women with superimposed preeclampsia $(\mathrm{p}=0.044)$ (Table 1$)$. The onset of the symptoms of the disease $(\mathrm{p}=0.669)$, severity of the symptoms ( $\mathrm{p}=0.447$ ), cesarean section rate $(\mathrm{p}=0.102)$, mean gestational week at delivery $(\mathrm{p}=0.410)$ and birth weight $(\mathrm{p}=0.340)$ were not significantly different between the two groups (Table 1 and Table 2). There were not significant differences in incidences of IUGR $(\mathrm{p}=0.434)$, stillbirths ( $\mathrm{p}=0.887$ ), early and late neonatal deaths $(\mathrm{p}=0.111, \mathrm{p}=0.848)$. Although maternal deaths and maternal near miss cases were not significantly different between the two groups $(\mathrm{p}=0.370)$, complication of eclampsia was significantly higher in women with preeclampsia $(\mathrm{p}=0.001)$ (Table 2).

\section{DISCUSSION}

The risk of hypertensive disorders in pregnancy increases gradually with advancing maternal age and underlying diseases. As expected, in superimposed preeclampsia group, maternal age, parity and systemic diseases such as diabetes mellitus were more frequent when compared with preeclampsia group. These results were similar to the findings of Tuuli et al. Unlike Tuuli et al, we did not find a significant difference between the two groups in terms of smoking. ${ }^{2}$ There are conflicting reports in the literature concerning the relationship between smoking and risk of preeclampsia in chronic hypertension. Chappell et al. found that smoking was an independent risk factor for superimposed preeclampsia, while others did not find any relation. ${ }^{5-7}$ 
Although Tuuli et al. did not find significant difference between the groups in terms of fetal gender, we found male predominance in women with superimposed preeclampsia. ${ }^{2}$ We don't know whether that's a coincidence. Further research is needed to identify the role of fetal gender in women with superimposed preeclampsia.

Tuuli at al. revealed that women with superimposed preeclampsia have significantly higher risk of preterm delivery at 34 weeks of gestation (17.3\% vs $8.7 \%)$, preterm delivery at 37 weeks of gestation (43.8\% vs $27.8 \%)$ and cesarean delivery $(46.2 \%$ vs $36.3 \%)$, when compared with preeclamptic women. ${ }^{2}$ Roberts et al. also found increased risk of cesarean delivery in women with superimposed preeclampsia compared with preeclampsia group. ${ }^{8}$ Those two studies did not declare any difference in IUGR and stillbirth rates between the two groups. ${ }^{2,8}$ Similar to these studies, we did not find any difference in IUGR and stillbirth rates between the two groups. As well as, no statistically significant difference was shown in rates of cesarean section, preterm delivery at 34 weeks of gestation and preterm delivery at 37 weeks of gestation in our cases. Tuuli et al. reported that superimposed preeclampsia have increased risks of intervention-related events compared to women with preeclampsia. Although there was not conclusive evidence, they concluded that superimposed preeclampsia tends to occur earlier in pregnancy and was a more severe condition. ${ }^{2}$ However, we found that onset of the symptoms and incidence of severity was not different between the two groups. Furthermore, eclampsia was more common in women with preeclampsia (2\% vs $14.2 \%)$ in contrast to study conducted by Tuuli et al. $(0.34 \%$ vs $0.30 \%)$. These differences can be attributed partially to the inclusion criteria and partially to the differences in the management regarding the timing of delivery. Vigil-De Gracia et al. stated that eclampsia was not detected in women with superimposed preeclampsia suggesting different pathophysiological abnormalities leading to development of eclampsia in women with or without chronic hypertension. ${ }^{9}$ The results of this study reinforced the hypothesis of Vigil-De Gracia et al.
Similar to our results; Vigil-De Gracia et al. did not find any difference in preterm delivery at 37 weeks of gestation between the groups. They also suggested that perinatal outcomes after expectant management were not different in women with superimposed preeclampsia compared to severe preeclampsia. ${ }^{10}$ In addition to these findings, we did not find significant differences in frequencies of neonatal and maternal deaths and maternal near miss cases between the two groups.

The timing of delivery is the most important management decision in both preeclampsia and superimposed preeclampsia. ACOG stated that previous studies focusing on the expectant management of preeclampsia typically excluded the subgroup of women with superimposed preeclampsia. ACOG concluded that there were higher risk of intervention- related events and morbidity among women with superimposed preeclampsia, thus raising the issue of potentially unnecessary iatrogenic preterm births with superimposed preeclampsia. ${ }^{3}$ They did not state any data to specifically address the management of superimposed preeclampsia, therefore evidence from the preeclampsia literature have to be used to guide management. According to ACOG guidelines, superimposed preeclampsia with severe features should be managed in a manner similar to severe preeclampsia and superimposed preeclampsia without severe features should be managed in a manner similar to preeclampsia without severe features. ${ }^{3}$

This study has some limitations. Because its retrospective nature it was limited by the records of patients. In cases without antenatal care, gestational ages at the onset of the disease were estimated based on hospital admission. We were not able to know exact onset time of the disease, especially in women with severe symptoms, if they were not admitted before. Because inadequate postpartum follow-up, women with chronic hypertension defined according to the persisting hypertension longer than 12 weeks postpartum mistakenly might be classified as preeclampsia instead of superimposed preeclampsia.

As a conclusion, despite initial fears to the contrary, superimposed preeclampsia does not re- 
sult in worse outcomes than preeclampsia, if it is managed in a manner similar to preeclampsia. This article reported outcomes of preeclampsia and superimposed preeclampsia separately. It supports ACOG's recommendations. We hope it will encourage researchers to identify why eclampsia develops more commonly in preeclampsia.

\section{Acknowledgements}

Authors declare no any acknowledgement.

\section{Conflict of Interest}

Authors declared no conflict of interest or financial support.

\section{Authorship Contributions}

All authors planned to produce this study, analyzed the data, reviewed the literature to design it and revised it for final approval of the version to be published.

\section{REFERENCES}

1. Liu X, Ruan Y, Liu Y, Zhang W. [Relationship between maternal age and hypertensive disorders in pregnancy]. Zhonghua Yi Xue Za Zhi 2015;95(1):19-22.

2. Tuuli MG, Rampersad R, Stamilio D, Macones G, Odibo AO. Perinatal outcomes in women with preeclampsia and superimposed preeclampsia: do they differ? Am J Obstet Gynecol 2011;204(6):508.e1-7.

3. American College of Obstetricians and Gynecologists, Task Force on Hypertension in Pregnancy. Hypertension in pregnancy. Report of the American College of Obstetricians and Gynecologists' Task Force on Hypertension in Pregnancy. Obstet Gynecol 2013; 122(5):1122-31.

4. Report on the World Health Organization Working Group on the Classification of Mater- nal Deaths and Severe Maternal Morbidities. Geneva: World Health Organization; 2009; 87: 733-804.

5. Chappell LC, Enye S, Seed P, Briley AL, Poston L, Shennan AH. Adverse perinatal outcomes and risk factors for preeclampsia in women with chronic hypertension: a prospective study. Hypertension 2008;51(4): 1002-9.

6. Lecarpentier E, Tsatsaris V, Goffinet F, Cabrol D, Sibai B, Haddad B. Risk factors of superimposed preeclampsia in women with essential chronic hypertension treated before pregnancy. PLoS One 2013;8(5): e62140.

7. Sibai BM, Koch MA, Freire S, Pinto e Silva JL, Rudge MV, Martins-Costa S, et al. The impact of prior preeclampsia on the risk of superim- posed preeclampsia and other adverse pregnancy outcomes in patients with chronic hypertension. Am J Obstet Gynecol 2011; 204(4):345.e1-6.

8. Roberts $\mathrm{CL}$, Algert CS, Morris JM, Ford JB, Henderson-Smart DJ. Hypertensive disorders in pregnancy: a population-based study. Med J Aust 2005;182(7):332-5.

9. Vigil-De Gracia P, Montufar-Rueda C, Smith A. Pregnancy and severe chronic hypertension: maternal outcome. Hypertens Pregnancy 2004;23(3):285-93.

10. Vigil-De Gracia P, Montufar-Rueda C, Ruiz J. Expectant management of severe preeclampsia and preeclampsia superimposed on chronic hypertension between 24 and 34 weeks' gestation. Eur J Obstet Gynecol Reprod Biol 2003;107(1):24-7. 